\title{
Lixisenatide as add-on therapy to basal insulin
}

\author{
This article was published in the following Dove Press journal: \\ Drug Design, Development and Therapy \\ 12 December 2013 \\ Number of times this article has been viewed
}

\section{Dominique Xavier Brown \\ Emma Louise Butler \\ Marc Evans}

Diabetes Department, University Hospital Llandough, Cardiff, UK
Correspondence: Dominique Xavier Brown

Diabetes Department, University

Hospital Llandough, Cardiff,

CF64 2XX, UK

Tel +442921I5 5725

Email browndx@cf.ac.uk
Abstract: Many patients with type 2 diabetes mellitus do not achieve target glycosylated hemoglobin $\mathrm{A}_{1 \mathrm{c}}$ levels despite optimally titrated basal insulin and satisfactory fasting plasma glucose levels. Current evidence suggests that $\mathrm{HbA}_{1 \mathrm{c}}$ levels are dictated by both basal glucose and postprandial glucose levels. This has led to a consensus that postprandial glucose excursions contribute to poor glycemic control in these patients. Lixisenatide is a once-daily, prandial glucagon-like peptide 1 (GLP-1) receptor agonist with a four-fold affinity for the GLP-1 receptor compared with native GLP-1. Importantly, lixisenatide causes a significant delay in gastric emptying time, an important determinant of the once-daily dosing regimen. An exendin-4 mimetic with six lysine residues removed at the C-terminal, lixisenatide has pronounced postprandial glucose-lowering effects, making it a novel incretin agent for use in combination with optimally titrated basal insulin. Lixisenatide exerts profound effects on postprandial glucose through established mechanisms of glucose-dependent insulin secretion and glucagon suppression in combination with delayed gastric emptying. This review discusses the likely place that lixisenatide will occupy in clinical practice, given its profound effects on postprandial glucose and potential to reduce glycemic variability.

Keywords: lixisenatide, add-on therapy, insulin, GLP-1 receptor agonist, postprandial glucose, pharmacodynamics

\section{Incretin therapies}

The pathogenesis of type 2 diabetes mellitus (T2DM) is often associated with a dysregulation of the incretin system, resulting in a reduction of the "incretin effect". ${ }^{1,2}$ The incretin effect can be described as an amplification of insulin biosynthesis and secretion due to the action of two key hormones, glucagon-like peptide 1 (GLP-1) and glucose-dependent insulinotropic polypeptide (GIP). ${ }^{2}$ In normal circumstances, GLP-1 and GIP are released from the gastrointestinal tract in response to oral food intake, stimulating the release of insulin from pancreatic beta-cells. ${ }^{3}$ In T2DM, release of the incretin hormones in response to oral food intake is reduced, resulting in decreased insulin synthesis and secretion. ${ }^{3}$ Arguably, GLP-1 mediates most of the incretin effect and hence current therapies have focused on GLP-1 rather than GIP. ${ }^{4}$

Currently, two distinct pharmacologic strategies exist to target the incretin system in T2DM. The first involves creating GLP-1 mimetics that are agonists at the GLP-1 receptor, and exert direct, pharmacologic, intrinsic biological activity. The second involves inhibiting the endogenous dipeptidyl peptidase-4 (DPP-4) enzyme. DPP-4 mediates the breakdown of GLP-1 and GIP, hence its inhibition results in increased GLP-1 and GIP levels. ${ }^{5-7}$ The incretin therapies are established as effective 
second-line or third-line agents in the treatment of T2DM, and generally demonstrate an acceptable safety and tolerability profile..$^{8,9}$

\section{GLP-I receptor agonists in clinical practice}

The GLP-1 receptor agonists available are liraglutide, exenatide twice daily, and exenatide once weekly, with lixisenatide having also recently received regulatory approval by the European Medicines Agency in Europe. ${ }^{10}$ In addition, numerous DPP-4 inhibitors are available, including sitagliptin, linagliptin, saxagliptin, vildagliptin (in Europe), and alogliptin. ${ }^{5,11-13}$ The current National Institute for Health and Clinical Excellence guidelines state that GLP-1 receptor agonists should be used as a third-line treatment option in patients with suboptimal glycemic control, ie, glycosylated hemoglobin $\mathrm{A}_{1 \mathrm{c}}\left(\mathrm{HbA}_{1 \mathrm{c}}\right)>58 \mathrm{mmol} / \mathrm{mol}(7.5 \%)$ and body mass index $>35 \mathrm{~kg} / \mathrm{m}^{2}$, or in patients with body mass index $<35 \mathrm{~kg} / \mathrm{m}^{2}$ where weight reduction is considered

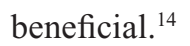

Certain GLP-1 receptor agonists such as exenatide twice daily are currently approved as add-on therapy to exogenous insulin. It is worth mentioning that the efficacy of stand-alone exenatide twice daily in terms of prandial glucose control has also been proven; however, combination therapy with insulin has several benefits. ${ }^{15}$ These include improved glycemic control, reduced body weight, reduced insulin dose requirement, and possible improvements in symptomatic hypoglycemia. ${ }^{16-18}$

\section{Current GLP-I agonists used in combination with basal insulin}

Exenatide twice daily is currently licensed as add-on therapy to basal insulin in the US and Europe, whilst exenatide once weekly is not. ${ }^{19,20}$ Liraglutide was licensed by the US Food and Drug Administration for use in combination with any basal insulin on April 12, 2013, ${ }^{21}$ although this is not considered a prandial incretin agent. ${ }^{22}$ One of the major glycemic objectives of combination basal insulin/GLP-1 agonist therapy is the potential complementary glycemic effects with respect to both fasting and postprandial glucose (PPG). Such a concept is supported by observations suggesting that targeting fasting plasma glucose increases the contribution of PPG to overall glycemia. In addition, although the incretin therapies in general have a good safety and tolerability profile, compliance is still an issue because adverse events of nausea and vomiting are still apparent. This brings into question the utility of GLP-1 receptor agonists with a more preferential prandial glucose-lowering effect for use in combination with exogenous basal insulin. This review focuses on the potential role of lixisenatide in this context, particularly based on reported tolerability and prandial glucose-lowering effects. ${ }^{23,24}$

\section{What is lixisenatide?}

Lixisenatide is a selective, potent, once-daily GLP-1 receptor agonist developed by Sanofi in partnership with Zealand Pharma, ${ }^{25}$ and is administered subcutaneously. Lixisenatide was approved on February 1, 2013 by the European Medicines Agency, and will be included in the update to the National Institute for Health and Clinical Excellence type 2 diabetes clinical guideline, expected to be published in the second quarter of $2014 .{ }^{26,27}$ Similar to exenatide, it is based on the structure of exendin-4 and shares approximately $50 \%$ homology. Lixisenatide consists of a 44-amino acid peptide modified at the C-terminal with the removal of a proline residue and addition of six lysine residues. Lixisenatide is more resistant to proteolysis than native GLP-1, and has a short half-life of 1.5-4.5 hours. However, lixisenatide can be administered once daily, making it more convenient than exenatide twice daily due to a four-fold higher affinity for the GLP-1 receptor compared with native GLP-1, resulting in a strong delaying effect on gastric emptying. ${ }^{25,28,29}$ In the US, exenatide once weekly is currently licensed; however, this has limited the postprandial benefit. ${ }^{30}$ As of yet, lixisenatide appears to carry a low risk for hypoglycemia, like other incretin therapies, and has the following positive actions: reduces $\mathrm{HbA}_{1 \mathrm{c}}$; reduces fasting plasma glucose; markedly reduces PPG; promotes weight loss; and reduces the requirement for exogenous insulin (Table 1). Lixisenatide may significantly reduce PPG via mechanisms of increased insulin secretion and suppression of glucagon. However, a clinical study involving administration of lixisenatide $20 \mu \mathrm{g}$ each morning has also established the significant effect of lixisenatide on blood glucose throughout the day, that is at least in part due to delayed gastric emptying. ${ }^{31}$

The GetGoal program has established that lixisenatide therapy initiated in a one-step dose is equally as effective and more convenient than a two-step dose increase. ${ }^{32}$ Therefore, lixisenatide is licensed to be administered initially at a dose of $10 \mu \mathrm{g}$ once daily for 14 days and then increased to $20 \mu \mathrm{g}$ once daily (one-step). The key novel difference between lixisenatide and the other GLP-1 receptor agonists is arguably the former's pronounced effect on PPG. ${ }^{25}$ Therefore, an explanation of how PPG contributes to overall glycemic control is important in order to comprehend the place lixisen- 
atide may have in clinical practice. Barnett has previously discussed the evidence for use of lixisenatide back in 2011,25 so the focus of this paper is on the position lixisenatide may occupy in clinical practice, namely in addition to optimally titrated basal insulin.

\section{Postprandial glucose}

Recent best evidence suggests that loss of PPG control may be the first step in development of T2DM. ${ }^{33,34}$ This is followed by loss of adequate glycemic control in prebreakfast and postbreakfast periods. ${ }^{34}$ The contribution of PPG to hyperglycemia has been found to be particularly relevant at low but still suboptimal $\mathrm{HbA}_{1 \mathrm{c}}$ levels. Therefore, targeting fasting plasma glucose alone may not be sufficient to achieve target $\mathrm{HbA}_{1 \mathrm{c}}$ levels, particularly when current oral antidiabetic agents have been demonstrated to increase the contribution of PPG to overall glycemia from approximately $20 \%-24 \%$ to $59 \%-69 \% .{ }^{35}$ Novel agents that target PPG have the potential to provide an answer to this challenge and may also have an independent beneficial effect on microvascular and macrovascular diabetic outcomes. While the evidence relating to the impact of PPG excursions on hard diabetic endpoints is slowly gathering, it remains lacking. ${ }^{24,36}$ This is mainly due to the fact that studies on PPG have rarely been interventional and rather have been pathophysiologic reports, cohort studies, epidemiologic, trials, or meta-analyses. ${ }^{37}$ On the other hand, there is significant evidence to suggest that surrogate markers of glycemic control, such as $\mathrm{HbA}_{1 \mathrm{c}}$ '

Table I Advantages and disadvantages of lixisenatide therapy

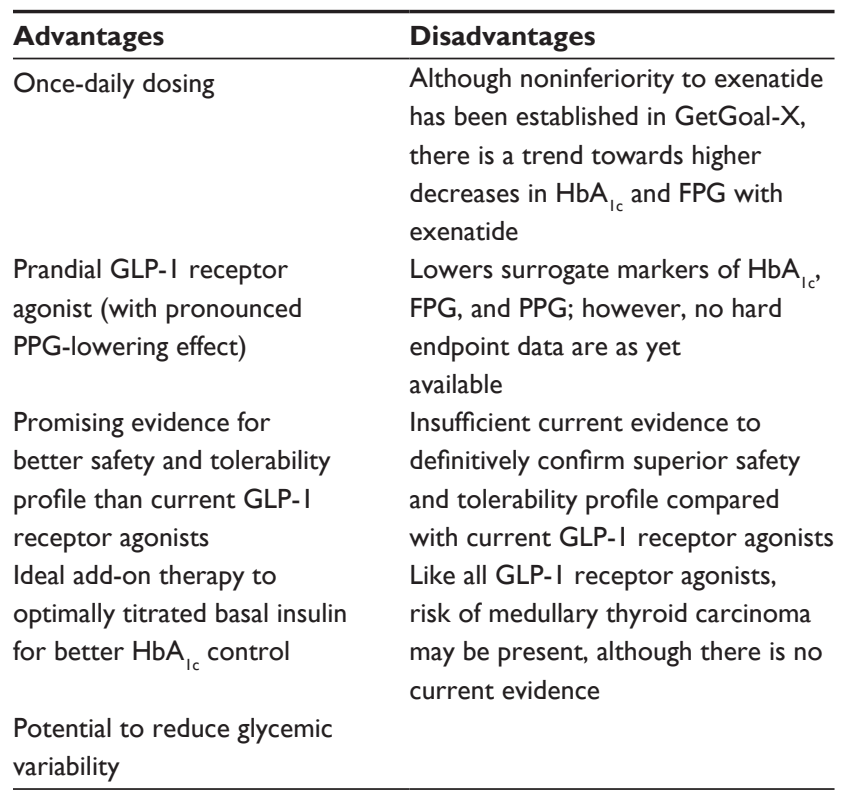

Abbreviations: FPG, fasting plasma glucose; PPG, postprandial glucose; $\mathrm{HbA}_{\mathrm{Ic}}$, glycosylated hemoglobin; GLP-I, glucagon-like peptide I. are determined by both basal glucose levels and PPG. ${ }^{33,38,39}$ Monnier et al conducted a study in 140 noninsulin-using diabetics in 2007. The results showed that for individuals with $\mathrm{HbA}_{1 \mathrm{c}}$ levels $>48 \mathrm{mmol} / \mathrm{mol}$ (6.5\%), PPG excursions contributed about $1 \%$ to this $\mathrm{HbA}_{1 \mathrm{c}}$ figure, and in individuals with $\mathrm{HbA}_{1 \mathrm{c}}$ levels $<48 \mathrm{mmol} / \mathrm{mol}$ (6.5\%), PPG excursions were found to contribute about $0.7 \% .{ }^{33}$ Uncontrolled $\mathrm{HbA}_{1 \mathrm{c}}$ is a significant risk factor for diabetic complications, so the impact that PPG may have on diabetic complications should be strongly considered..$^{33}$

\section{Mechanism of PPG reduction by lixisenatide}

In nondiabetic individuals, PPG is tightly regulated by three principal mechanisms, ie, an increase in insulin secretion from beta-cells, suppression of glucagon secretion by alpha-cells, and a slowing in the rate of gastric emptying. Lixisenatide impacts on all three of these critical factors, which may explain the profound effects exerted on PPG (Table 2). The insulinotropic and glucagonostatic effects of lixisenatide are common to all GLP-1 receptor agonists, which share the same mechanism. This is thought to occur by activation of GLP-1 receptor-mediated cAMP signaling, as demonstrated by Sloop et al in rodent and human islet cells. ${ }^{40}$ A recent study by Lorenz et al investigated the relationship between the effect lixisenatide exerts on gastric emptying and its effects on PPG. Theirs was a 28-day, randomized, double-blind, placebo-controlled, parallel-group study in patients with T2DM currently taking up to two oral antidiabetic agents. Lixisenatide was administered subcutaneously once daily using an ascending dose-escalation strategy beginning at $5 \mu \mathrm{g}$ and increasing by $2.5 \mu \mathrm{g}$ every 4 days until a final dose of $20 \mu \mathrm{g}$ was achieved between days 25 and $28 .^{31}$

PPG was assessed by 24-hour blood glucose monitoring and gastric emptying by a ${ }_{13} \mathrm{C}$-octanoic acid breath test

Table 2 Overview of the established mechanisms by which lixisenatide reduces postprandial glucose in preclinical and clinical studies

\begin{tabular}{lll}
\hline Lixisenatide mechanism & $\begin{array}{l}\text { Preclinical } \\
\text { studies }\end{array}$ & $\begin{array}{l}\text { Clinical } \\
\text { studies }\end{array}$ \\
\hline Stimulates insulin secretion & $\checkmark$ & $\checkmark$ \\
Suppresses glucagon secretion & $\checkmark$ & $\checkmark$ \\
Increases insulin biosynthesis & $\checkmark$ & \\
Stimulates beta-cell proliferation & $\checkmark$ & \\
Prevents islet cell depletion & $\checkmark$ & \\
Preserves $\beta$-cell function & $\checkmark$ & $\checkmark^{31}$ \\
Delays gastric emptying & $\checkmark$ & \\
\hline
\end{tabular}


at day 28. The results demonstrated that, on day 28 , the area under the concentration-time curve for PPG was significantly reduced after breakfast, lunch, and dinner, as compared with placebo ( $P=0.0001, P=0.0004$, and $P=0.0082$, respectively). In accordance with this, the mean gastric emptying half-life was significantly increased in the lixisenatide cohort as compared with placebo $(P=0.0031)$. Lorenz et al concluded that a significant proportion of the effect of lixisenatide on PPG is therefore mediated by a delay in gastric emptying. It is of note that there are parallels between the end results of delayed gastric emptying and increased insulin secretion that result in decreased PPG levels with lixisenatide and beta-glucans (soluble dietary fiber). There is evidence to suggest that beta-glucans attenuate PPG excursions and reduce the risk of T2DM and cardiovascular disease. ${ }^{41,42}$ However, although they share some characteristics resulting in decreased PPG, the effect of beta-glucans seems to be largely related to their level of viscosity, whereas lixisenatide exerts intrinsic pharmacologic activity at GLP-1 receptors. The introduction of lixisenatide into routine clinical practice in Europe may highlight whether there is a beneficial effect of combining increased intake of beta-glucans with lixisenatide therapy. ${ }^{42}$

\section{Lixisenatide versus liraglutide: pharmacodynamic comparison}

Liraglutide is the only other licensed GLP-1 receptor agonist, and is administered once daily, so provides a good comparator to assess the PPG-lowering effects of lixisenatide. Kapitza et al conducted a 4-week, randomized, multicenter, open-label study comparing the efficacy and safety of lixisenatide with that of the currently licensed GLP-1 agonist, liraglutide, in 148 patients (baseline $\mathrm{HbA}_{1 \mathrm{c}} 48-75 \mathrm{mmol} / \mathrm{mol}$ [6.5\%-9.0\%]) with T2DM inadequately controlled on metformin $\geq 1.5 \mathrm{~g} /$ day. Patients were randomized to receive a daily subcutaneous $10 \mu \mathrm{g}$ dose of lixisenatide for weeks $1-2$ and $20 \mu \mathrm{g}$ for weeks $3-4$, or $0.6 \mathrm{mg}$ liraglutide in week 1 , $1.2 \mathrm{mg}$ in week 2 , and $1.8 \mathrm{mg}$ in weeks $3-4$ as add-on therapy to metformin. The primary outcome was change in PPG levels from baseline at week $4 .{ }^{34}$

PPG and maximum PPG excursion were significantly reduced in the lixisenatide cohort as compared with the liraglutide cohort $(P<0.0001)$, with more patients in the lixisenatide cohort achieving a 2-hour PPG $<140 \mathrm{mg} / \mathrm{dL}$. The significantly greater improvements in PPG with lixisenatide as compared with liraglutide resulted in more patients achieving the required 2-hour PPG target ( $<7.8 \mathrm{mmol} / \mathrm{L})$ at day 28 following the breakfast test ( $69 \%$ versus $29 \%$, respectively).
Overall plasma glucose levels decreased in both cohorts. Glucagon levels were also significantly lower in the lixisenatide cohort $(P=0.032)$, and there was a significant reduction in postprandial insulin and C-peptide levels (both $P$-values $<0.0001)$. There was no significant difference in proinsulin reduction. $\mathrm{HbA}_{1 \mathrm{c}}$ was reduced in both cohorts, ie, $55(7.2 \%)$ to $52 \mathrm{mmol} / \mathrm{mol}(6.9 \%)$ with lixisenatide and $57(7.4 \%)$ to $52 \mathrm{mmol} / \mathrm{mol}(6.9 \%)$ with liraglutide. Body weight also decreased in both cohorts, although to a greater extent in the liraglutide cohort than in the lixisenatide cohort ( $-2.4 \mathrm{~kg}$ versus $-1.6 \mathrm{~kg}$, respectively).

The incidence of adverse events was lower in the lixisenatide cohort, with 45 (58.4\%) patients experiencing adverse events compared with $52(73.2 \%)$ in the liraglutide cohort. This was principally due to a reduction in the adverse events of decreased appetite, nervous system disorders, and gastrointestinal disorders. However, the incidences of nausea and vomiting were largely similar. There were no reports of serious adverse events in the study. There were four cases of treatment discontinuation relating to adverse events, ie, two $(2.6 \%)$ in the lixisenatide cohort resulting from drug hypersensitivity and an injection site rash, and two $(2.8 \%)$ in the liraglutide cohort resulting from adverse gastrointestinal events. No cases of symptomatic hypoglycemia were reported.

\section{Analysis of PPG-lowering effects of lixisenatide}

After 28 days of treatment, lixisenatide demonstrated a greater reduction in PPG after the breakfast test than liraglutide. Previous evidence suggests that GLP-1 receptor agonists exert their glucose-lowering action via a combination of insulinotropic and glucagonostatic effects together with a slowing of gastric emptying time. ${ }^{43}$ Delayed gastric emptying is a particularly important mechanism in the postprandial period, where decreased appearance of glucose in the systemic circulation results in decreased PPG excursions. ${ }^{44,45}$ In this study, insulin secretion was decreased to a greater extent with lixisenatide than with liraglutide. Concordant with the results reported by Lorenz et al, ${ }^{31}$ in the context of markedly decreased PPG, the decrease in insulin is consistent with a slowing of gastric emptying. ${ }^{34}$

Upon dose initiation on day 28, lixisenatide appeared to almost completely blunt the postprandial rise in plasma glucose, while a more modest decrease was seen with liraglutide. This effect was maintained throughout the day, as demonstrated in the 24-hour plasma glucose profile conducted on day 28. However, it was most apparent following 
the first meal of the day. Postprandial hyperglycemia following the first meal of the day is common in individuals with low but still suboptimal $\mathrm{HbA}_{1 \mathrm{c}}$ levels of approximately $62 \mathrm{mmol} / \mathrm{mol}(7.0 \%-8.0 \%) .^{33}$ These results therefore indicate that such individuals may benefit from a prandial incretin agent such as lixisenatide. As discussed later, this may also help to reduce glycemic variability, leading to better cardiovascular outcomes. ${ }^{46}$

Overall, 28 days of treatment with lixisenatide prebreakfast resulted in a significantly greater reduction in PPG as compared with liraglutide following a breakfast test. Adverse events were also decreased with lixisenatide, notably gastrointestinal events, that are a significant reason for noncompliance with GLP-1 receptor agonists. Postprandial insulin, C-peptide, and glucagon were also significantly decreased with lixisenatide, consistent with previous studies indicating that slowing of gastric emptying is a key mechanism.

\section{Clinical studies}

The GetGoal Phase III clinical trial program comprises clinical studies designed to assess the efficacy and safety of lixisenatide as monotherapy and combination therapy. ${ }^{25}$ Over 5,000 patients were recruited in a worldwide program involving 50 countries and 900 sites (Table 3). This section focuses on the GetGoal studies assessing lixisenatide as add-on therapy to basal insulin and the rationale behind this intuitive combination, because this potentially is the most anticipated future direction of lixisenatide in clinical practice.

\section{Lixisenatide as add-on therapy to oral antidiabetic agents}

Although not the focus of this review, the combination of lixisenatide and oral antidiabetic agents is a primary license indication for lixisenatide, so a brief overview of the two most pertinent studies is provided to give additional insight into the efficacy and safety of lixisenatide (Table 3). GetGoal-S and GetGoal-P assessed the efficacy of lixisenatide in combination with a sulfonylurea and pioglitazone, respectively. The primary outcome in both studies was change in $\mathrm{HbA}_{1 \mathrm{c}}$ from baseline at 24 weeks.

\section{Analysis of efficacy and safety as add-on therapy}

Both GetGoal-S ${ }^{47}$ and GetGoal- $\mathrm{P}^{48}$ demonstrated that, in combination with a sulfonylurea or pioglitazone, lixisenatide significantly reduced $\mathrm{HbA}_{1 \mathrm{c}}$, fasting plasma glucose, and body weight compared with placebo (all $P$-values $<0.0001$,
Table 3). Significantly more patients were able to achieve a target $\mathrm{HbA}_{1 \mathrm{c}}$ of $<53 \mathrm{mmol} / \mathrm{mol}(7.0 \%)$ in both studies $(P<0.0001)$. PPG was only assessed in GetGoal-S, and was profoundly decreased with lixisenatide as compared with placebo, consistent with preclinical studies $(P<0.0001)$. Both these studies demonstrate the benefit of lixisenatide as add-on therapy to oral antidiabetic agents in terms of efficacy. The profound decrease in PPG offers the prospect of reducing glycemic excursions significantly. Currently, one of the pitfalls of GLP-1 receptor agonist therapy is compliance, due to adverse events. GetGoal-S and GetGoal-P also demonstrated that lixisenatide has a favorable adverse event profile in combination with a sulfonylurea or pioglitazone, with a low risk of hypoglycemia.

\section{Head-to-head study: GetGoal-X}

An overview of GetGoal-X is provided to follow, indicating noninferiority of lixisenatide in terms of $\mathrm{HbA}_{1 \mathrm{c}}$ when compared with exenatide as add-on therapy to metformin with a predefined margin of $0.4 \%$.

GetGoal-X was a 24-week, randomized, open-label study ${ }^{49}$ comparing the efficacy and safety of lixisenatide with that of exenatide as add-on therapy to metformin in patients with inadequately controlled T2DM. The patients, of mean age 57.4 years, were randomized to receive $20 \mu \mathrm{g}$ of lixisenatide once daily or $10 \mu \mathrm{g}$ of exenatide twice daily, which was reached using a stepwise increase. The primary outcome of this noninferiority study was change in $\mathrm{HbA}_{10}$ from baseline at 24 weeks, with a predefined margin of $0.4 \% .{ }^{49}$ Exenatide twice daily provides a good comparator for lixisenatide because they are both based on the structure of exendin- 4 and are intermittent-release agents.

\section{Efficacy: head-to-head versus exenatide \pm metformin}

Lixisenatide was noninferior to exenatide in reducing $\mathrm{HbA}_{1 \mathrm{c}}$ levels at a predefined margin of $0.4 \%$, with mean decreases of $-15 \mathrm{mmol} / \mathrm{mol}(-0.8 \%)$ and $-13 \mathrm{mmol} / \mathrm{mol}(1.0 \%)$ for the lixisenatide and exenatide cohorts, respectively. The number of patients reaching a target $\mathrm{HbA}_{1 \mathrm{c}}$ of $<53 \mathrm{mmol} / \mathrm{mol}(7.0 \%)$ was similar, with $143(48.5 \%)$ in the lixisenatide cohort and $148(49.8 \%)$ in the exenatide cohort producing a nonsignificant $P$-value. Fasting plasma glucose was improved to a similar extent, with decreases of $-1.22 \mathrm{mmol} / \mathrm{L}$ and $-1.45 \mathrm{mmol} / \mathrm{L}$ for the lixisenatide and exenatide cohorts, respectively. There was a significant decrease in body weight in both cohorts, but to a larger extent on exenatide, with mean changes from baseline of -2.96 and -3.98 for lixisenatide and exenatide, respectively. 
Table 3 GetGoal Phase III clinical trial program: efficacy studies of lixisenatide either as monotherapy or combination therapy with various antidiabetic agents

\begin{tabular}{|c|c|c|c|c|c|}
\hline Study & Study type & Intervention & $\mathrm{HbA}_{\mathrm{lc}}(\%)$ & FPG $(\mathrm{mmol} / \mathrm{L})$ & PPG (mmol/L) \\
\hline $\begin{array}{l}\text { GetGoal-Mono }^{71} \\
(n=361)\end{array}$ & Efficacy in monotherapy & $\begin{array}{l}\text { Lixisenatide }^{\text {l-step }} \\
\text { Lixisenatide }^{2-\text { step }}\end{array}$ & $\begin{array}{l}-0.7^{* * *} \\
-0.5^{* * *}\end{array}$ & $\begin{array}{l}-1.1 * * * \\
-0.9 * *\end{array}$ & $\begin{array}{l}-3.7^{* * *} \\
-3.1^{* * *}\end{array}$ \\
\hline $\begin{array}{l}\text { GetGoal-FI } I^{32} \\
(n=482)\end{array}$ & $\begin{array}{l}\text { Efficacy combined with metformin } \\
\text { (I-step versus } 2 \text {-step dose } \\
\text { increase) }\end{array}$ & $\begin{array}{l}\text { Lixisenatide }^{\text {l-step }} \\
\text { Lixisenatide }^{2 \text {-step }}\end{array}$ & $\begin{array}{l}-0.5^{* *} \\
-0.4^{* * *}\end{array}$ & $\begin{array}{l}-0.53^{* *} \\
-0.56^{* * *}\end{array}$ & $\begin{array}{l}\text { N/A } \\
\text { N/A }\end{array}$ \\
\hline $\begin{array}{l}\text { GetGoal-M }{ }^{72} \\
(n=680)\end{array}$ & $\begin{array}{l}\text { Efficacy combined with metformin } \\
\text { (morning versus evening dose) }\end{array}$ & $\begin{array}{l}\text { Morning } \\
\text { lixisenatide } \\
\text { Evening } \\
\text { lixisenatide } \\
\text { 2-step }\end{array}$ & $\begin{array}{l}-0.9 * * * \\
-0.8^{* * * *}\end{array}$ & $\begin{array}{l}-1.19 * * \\
-0.81 * *\end{array}$ & $\begin{array}{l}-4.5^{*} \\
\text { NS }\end{array}$ \\
\hline $\begin{array}{l}\text { GetGoal-S47 } \\
(n=855)\end{array}$ & $\begin{array}{l}\text { Efficacy combined with a sulfonylurea } \pm \\
\text { metformin }\end{array}$ & Lixisenatide $^{2-\text { step }}$ & $-0.9 * * *$ & $-0.99 * * *$ & $-6.19 * * *$ \\
\hline $\begin{array}{l}\text { GetGoal-P48 } \\
(n=484)\end{array}$ & $\begin{array}{l}\text { Efficacy combined with pioglitazone } \pm \\
\text { metformin }\end{array}$ & Lixisenatide $^{2-\text { step }}$ & $-0.9 * * *$ & $-1.16 * * *$ & $\mathrm{~N} / \mathrm{A}$ \\
\hline $\begin{array}{l}\text { GetGoal-L Asia }{ }^{52} \\
(n=311)\end{array}$ & Efficacy with basal insulin \pm sulfonylurea & Lixisenatide $^{2-\text { step }}$ & $-0.8 * * *$ & $-0.4^{* *}$ & $-7.96 * * *$ \\
\hline $\begin{array}{l}\text { GetGoal-L } \\
(n=496)\end{array}$ & Efficacy with basal insulin \pm metformin & Lixisenatide ${ }^{2-s t e p}$ & $-0.7^{* *}$ & NS & $-5.54 * * *$ \\
\hline $\begin{array}{l}\text { GetGoal-Duo } I^{50} \\
(\mathrm{n}=898)\end{array}$ & $\begin{array}{l}\text { Efficacy in combination with optimally } \\
\text { titrated basal insulin } \pm \text { OAD }\end{array}$ & Lixisenatide estep $^{2}$ & $-0.7^{* * *}$ & +0.34 (NS) & $-3.09 * * *$ \\
\hline $\begin{array}{l}\text { GetGoal- } X^{49} \\
(n=634)\end{array}$ & $\begin{array}{l}\text { Head-to-head versus exenatide } \pm \\
\text { metformin (noninferiority) }\end{array}$ & Lixisenatide $^{2-\text { step }}$ & -0.8 & $-1.22(N S)$ & $\mathrm{N} / \mathrm{A}$ \\
\hline
\end{tabular}

Notes: All values are mean differences from baseline, significance level as compared with placebo. I-Step, I-Step dose increase of $10 \rightarrow 20 \mu g ; 2$-Step, 2-Step dose increase of $10 \rightarrow 15 \rightarrow 20 \mu \mathrm{g}$. $* P<0.05 ; * * P<0.005 ; * * * P<0.0005$. Noninferiority achieved at predefined margin of $0.4 \%$.

Abbreviations: $\mathrm{HbA}_{1 c}$, hemoglobin $\mathrm{A}_{l \mathrm{c}}$; $\mathrm{OAD}$, oral antidiabetic drug; FPG, fasting plasma glucose; PPG, postprandial glucose; NS, nonsignificant; NI, noninferior; $\mathrm{N} / \mathrm{A}$, not available.

\section{Safety and tolerability: head-to-head versus exenatide \pm metformin}

In total, $69.5 \%$ of patients in the lixisenatide cohort experienced an adverse event compared with $72.2 \%$ in the exenatide cohort, with treatment discontinuation necessary in $12.9 \%$ and $14.2 \%$ of patients in the lixisenatide and exenatide cohorts, respectively; the majority of these were due to adverse gastrointestinal events, with rates of $10.4 \%$ and $13.0 \%$ in the lixisenatide and exenatide cohorts, respectively (Table 4). The incidence of serious adverse events was similar, with nine $(2.8 \%)$ for lixisenatide and seven $(2.2 \%)$ for exenatide. Nausea was experienced by $24.5 \%$ and $35.1 \%(P<0.05)$ and vomiting by $10.1 \%$ and $13.3 \%$ (not statistically significant) of patients in the lixisenatide and exenatide cohorts, respectively. A significantly larger proportion of patients in the exenatide cohort experienced symptomatic hypoglycemia, ie, 25 (7.9\%) versus eight $(2.5 \%)$ in the lixisenatide cohort $(P<0.05)$, but there were no reported cases of severe hypoglycemia.

\section{Analysis of efficacy and safety}

In conclusion, GetGoal-X demonstrated lixisenatide to be noninferior to exenatide in terms of $\mathrm{HbA}_{1 \mathrm{c}}$ reduction, with weight loss in both cohorts and similar reductions in $\mathrm{HbA}_{1 \mathrm{c}}$ and fasting plasma glucose. There was, however, a trend towards a greater decrease in fasting plasma glucose with exenatide, which is to be expected given that lixisenatide is a prandial GLP-1 receptor agonist. PPG was not assessed, so a comparison is not possible, but a future 28-day study with a breakfast test may provide useful data. Notably, the study participants were required to have $\mathrm{HbA}_{1 \mathrm{c}}$ levels of 53-86 $\mathrm{mmol} / \mathrm{mol}(7 \%-10 \%)$ at baseline; this could have important implications for assessment of a prandial GLP-1 receptor agonist, because patients with $\mathrm{HbA}_{\mathrm{lc}}$ levels approaching $86 \mathrm{mmol} / \mathrm{mol}(10 \%)$ are less likely to benefit, given that the contribution of PPG to overall glycemia will be decreased in these individuals. In terms of safety and tolerability, adverse event rates were similar in both groups; however, overall, adverse gastrointestinal events were decreased in the lixisenatide cohort. In addition, the exenatide cohort experienced a higher incidence of symptomatic hypoglycemia. Gastrointestinal side effects are a significant reason for noncompliance with GLP-1 receptor agonists. There are currently not enough long-term data to determine whether the adverse event profile of lixisenatide is superior to that of exenatide, but the current evidence is promising. Overall, GetGoal-X has demonstrated that lixisenatide is noninferior to exenatide in terms of efficacy, and may have a better adverse event profile; however, with no PPG in the study data, conclusions relating to the prandial nature of lixisenatide are limited. 


\section{Lixisenatide as add-on therapy to basal insulin}

Three studies in the GetGoal program assessed the efficacy and safety of lixisenatide as add-on therapy to basal insulin, ie, GetGoal-Duo1, GetGoal-L, and GetGoal-L-Asia. The combination of lixisenatide and basal insulin is intuitive because both provide independent but complementary actions on PPG and fasting plasma glucose, respectively. As such, these studies are particularly relevant to the license indication for lixisenatide. The primary outcome of all three studies was change in $\mathrm{HbA}_{1 \mathrm{c}}$ from baseline at 24 weeks.

GetGoal-Duo1 was a 24-week randomized, doubleblind, multicenter study assessing the efficacy and safety of lixisenatide in T2DM patients with $\mathrm{HbA}_{1 \mathrm{c}} \geq 53(7.0 \%)$ and $\leq 75 \mathrm{mmol} / \mathrm{mol}(9.0 \%)$ as add-on therapy to optimally titrated insulin glargine and metformin \pm thiazolidinediones. During a run-in period of 12 weeks, all patients received weekly dose titration of insulin glargine to achieve a fasting plasma glucose target of $4.4-5.6 \mathrm{mmol} / \mathrm{L}$. On achieving this target at 12 weeks, the patients were randomized to receive $20 \mu \mathrm{g}$ of lixisenatide once daily or a volume-matched placebo with continuation of insulin glargine titration. ${ }^{50}$

GetGoal-L was a 24-week, randomized, double-blind, multicenter study assessing the safety and efficacy of lixisenatide compared with placebo as add-on therapy to basal insulin \pm metformin in a predominantly Caucasian, modified intention-to-treat population of 493 patients (mean $\mathrm{HbA}_{1 \mathrm{c}}$ at baseline $68 \mathrm{mmol} / \mathrm{mol}$ [8.4\%]). The patients were randomized 2:1 to receive $20 \mu \mathrm{g}$ of lixisenatide or a volume-matched placebo in a two-step dose increase. ${ }^{51}$

GetGoal-L-Asia was a 24-week study assessing the efficacy and safety of a once-daily $20 \mu \mathrm{g}$ dose of lixisenatide, against placebo, as add-on therapy to basal insulin with or without a sulfonylurea in 311 Asian patients with T2DM. The patients had a mean age of 58.4 years and received $10 \mu \mathrm{g}$ of lixisenatide or a volume-matched placebo in the first week, $15 \mu \mathrm{g}$ in the second week, and a $20 \mu \mathrm{g}$ maintenance dose for the remaining weeks of the study. ${ }^{52}$

\section{Efficacy}

\section{GetGoal-Duol:add-on therapy} to optimally titrated basal insulin \pm oral antidiabetic agents

$\mathrm{HbA}_{1 \mathrm{c}}$ decreased to a significantly greater extent in the lixisenatide cohort compared with placebo $(-0.7 \%$ versus $-0.4 \%$, respectively, mean difference $-0.3 \%, P<0.0001$, Figure 1). A markedly greater proportion of patients achieved
$\mathrm{HbA}_{1 \mathrm{c}}<53 \mathrm{mmol} / \mathrm{mol}$ (7.0\%), ie, 56\% compared with 39\% receiving placebo $(P=0.0001)$ and $\mathrm{HbA}_{1 \mathrm{c}}<48 \mathrm{mmol} / \mathrm{mol}$ (6.5\%), ie, $32 \%$ compared with $16 \%$ for placebo $(P<0.0001)$. Two-hour PPG values were significantly improved in the lixisenatide cohort, with a mean difference of $-3.16 \mathrm{mmol} / \mathrm{L}$ compared with placebo $(P<0.0001)$. Average seven-point selfmonitoring of blood glucose decreased by $-0.47 \mathrm{mmol} / \mathrm{L}$ for lixisenatide and by $-0.08 \mathrm{mmol} / \mathrm{L}$ for placebo (mean difference $-0.39 \mathrm{mmol} / \mathrm{L}, P=0.0071$ ). There was no significant difference in improvement of fasting plasma glucose, with a mean change of $+0.34 \mathrm{mmol} / \mathrm{L}$ for lixisenatide and $+0.46 \mathrm{mmol} / \mathrm{L}$ for placebo (mean difference $-0.12 \mathrm{mmol} / \mathrm{L}, P=0.5142$ ). Lixisenatide also had a favorable effect on body weight, with a mean difference of $-0.89 \mathrm{~kg}$ compared with placebo $(P=0.0012)$.

\section{GetGoal-L: add-on therapy to basal insulin \pm metformin}

$\mathrm{HbA}_{1 \mathrm{c}}$ was significantly improved in the lixisenatide cohort compared with the placebo cohort over 24 weeks, with a mean difference of $-0.36 \%(P<0.001)$ and more patients achieving $\mathrm{HbA}_{1 \mathrm{c}}<53 \mathrm{mmol} / \mathrm{mol}(7.0 \%)$, ie, $28 \%$ of the lixisenatide cohort versus $12 \%$ receiving placebo $(P<0.0001$, Figure 2$)$. Two-hour PPG after a standardized breakfast test was significantly improved in the lixisenatide cohort as compared with placebo, with a mean difference of $-3.81 \mathrm{mmol} / \mathrm{L}(P<0.0001)$, but there was no significant difference in the effect on fasting plasma glucose between the two cohorts. At 24 weeks, the basal insulin dose requirement was decreased more in the lixisenatide cohort than in the placebo cohort ( -5.6 versus $-1.9 \mathrm{U} /$ day, respectively, $P=0.012$ ). Body weight was also decreased to a greater extent in the lixisenatide cohort, with a mean difference of $-1.28 \mathrm{~kg}(-1.8$ versus $-0.5 \mathrm{~kg}$, respectively, $P<0.0001)$.

\section{GetGoal-L-Asia: add-on therapy to basal insulin \pm sulfonylureas}

Lixisenatide significantly reduced $\mathrm{HbA}_{1 \mathrm{c}}$ as compared with placebo, with a mean difference of $-0.89 \%(P<0.0001$, Figure 3$)$. The proportion of patients achieving $\mathrm{HbA}_{1 \mathrm{c}}<53(7 \%)$ and $<48 \mathrm{mmol} / \mathrm{mol}(6.5 \%)$ was significantly higher in the lixisenatide cohort $(35.6 \%$ versus $5.2 \%$ for $<53 \mathrm{mmol} / \mathrm{mol}$ [7\%] and 17.8 versus $1.3 \%$ for $<48 \mathrm{mmol} / \mathrm{mol}$ [6.5\%], both $P$-values $<0.0001)$. Two-hour PPG and two-hour PPG excursions were significantly decreased in the lixisenatide cohort at week 24 compared with the placebo cohort $(-7.96 \mathrm{mmol} / \mathrm{L}$ versus $-0.14 \mathrm{mmol} / \mathrm{L}$ for 2 -hour PPG and $-7.09 \mathrm{mmol} / \mathrm{L}$ versus $+0.14 \mathrm{mmol} / \mathrm{L}$ for 2-hour PPG excursions, respectively, $P<0.0001)$. There were significant improvements in the lixisenatide cohort for fasting plasma glucose, with 
average changes of $-0.42 \pm 0.31 \mathrm{mmol} / \mathrm{L}$ for lixisenatide versus $+0.25 \pm 0.30 \mathrm{mmol} / \mathrm{L}$ for placebo $(P=0.0187)$ and of seven-point self-monitored blood glucose $(1.91 \pm 0.27 \mathrm{mmol} / \mathrm{L}$ for lixisenatide versus $-0.56 \pm 0.27 \mathrm{mmol} / \mathrm{L}$ for placebo). The dose requirement for basal exogenous insulin was significantly lower on lixisenatide $(1.39 \pm 0.46 \mathrm{U})$ than on placebo $(-0.11 \pm 0.44 \mathrm{U})$ at week $24(P=0.0019)$. No statistically significant difference in body weight change was observed between the two cohorts, but this was generally decreased in the lixisenatide cohort $(-0.38 \mathrm{~kg}$ versus $+0.06 \mathrm{~kg}, 95 \%$ confidence interval $-0.925,0.061 ; P=0.0857)$.

\section{Analysis of efficacy as add-on therapy to basal insulin}

All three studies demonstrated a significant decrease in both $\mathrm{HbA}_{1 \mathrm{c}}$ levels and insulin dose requirement with lixisenatide compared with placebo as add-on therapy to basal insulin. This allowed significantly more patients in all studies to achieve their respective $\mathrm{HbA}_{1 \mathrm{c}}$ targets. As expected, 2-hour PPG was significantly decreased in all studies, whilst fasting plasma glucose was only decreased in GetGoal-L-Asia. Given the significant $\mathrm{HbA}_{1 \mathrm{c}}$ decreases in all studies, this is consistent with evidence showing that when fasting plasma glucose targets are achieved, the contribution of PPG to overall glycemia is increased. This is especially relevant in patients treated with basal insulin, who have often achieved target fasting plasma glucose levels and required a complementary prandial glucose targeting strategy to achieve $\mathrm{HbA}_{1 \mathrm{c}}$ targets. Fasting plasma glucose may have been impacted more in GetGoal-L-Asia because, in Asian populations, T2DM is characterized by a more profound deficit in insulin secretion rather than insulin sensitivity. ${ }^{53-55}$ In GetGoal-L and GetGoal-Duo1, body weight was significantly reduced with lixisenatide compared with placebo; this was not the case in GetGoal-L-Asia, but there was a trend towards a decrease in the latter study.
The traditional approach to minimizing the impact of postprandial hyperglycemia has been to initiate rapid-acting insulin at mealtimes. However, this entails additional selfmeasured plasma glucose tests to achieve the correct dosing, probable multiple injections, and a risk of hypoglycemia. Additionally, the use of adjunct mealtime insulin comes with the caveat of weight gain. Based on the GetGoal studies, lixisenatide appears to exert similar effects on $\mathrm{HbA}_{1 \mathrm{c}}$ with a single injection, having the net effect of weight loss rather than weight gain, and no need for additional self-measured plasma glucose tests. ${ }^{50,56}$ Overall, these studies demonstrate that lixisenatide improves glycemic control and reduces the insulin dose requirement by targeting PPG excursions. There is also evidence to suggest that lixisenatide may be beneficial in reducing body weight as add-on therapy to basal insulin.

\section{Safety and tolerability GetGoal-Duol: add-on therapy to optimally titrated basal insulin \pm oral antidiabetic agents}

Eighty percent of patients in the lixisenatide cohort experienced adverse events compared with $68 \%$ of those in the placebo cohort, with an increased incidence of nausea $(27.4 \%$ versus $9.4 \%$ ) and vomiting (4.9\% versus $1.3 \%$ ), respectively (Table 5). Discontinuation of treatment was also more common in the lixisenatide cohort than in the placebo cohort ( $8.5 \%$ versus $3.6 \%$, respectively). Symptomatic hypoglycemia occurred in a higher proportion of patients on lixisenatide $(22.4 \%)$ than in those on placebo $(13.5 \%)$.

\section{GetGoal-L: add-on therapy to basal insulin \pm metformin}

Adverse events occurred in $73.5 \%$ versus $68.3 \%$ of the lixisenatide and placebo cohorts, respectively, and serious adverse events in $3.7 \%$ versus $4.2 \%$. Treatment was
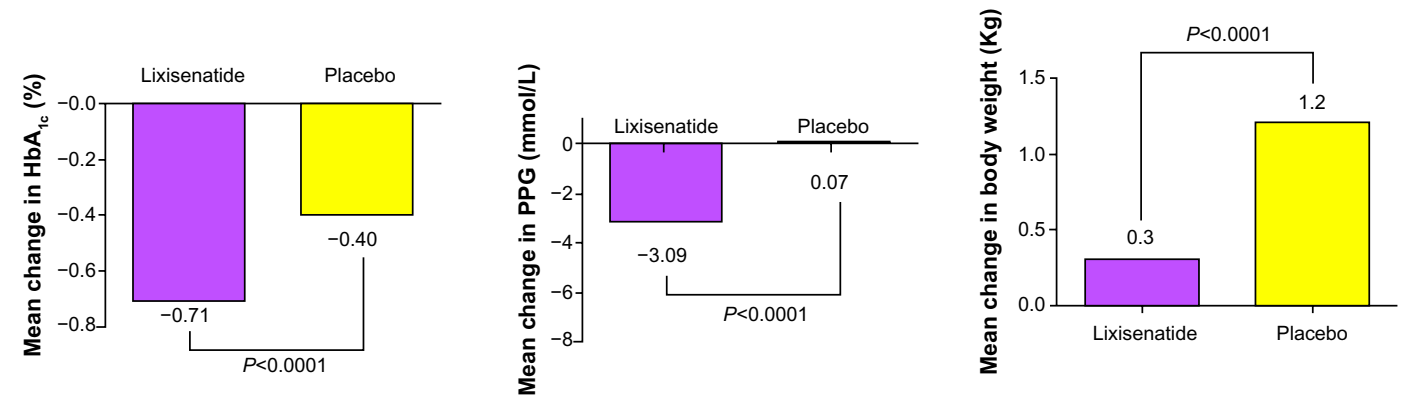

Figure I (A) Mean reduction in $\mathrm{HbA}_{\mathrm{Ic}}$ from baseline at 24 weeks achieved by lixisenatide as compared with placebo in the GetGoal-Duo I study ${ }^{50}(P<0.000 \mathrm{I})$. (B) Mean reduction in PPG from baseline at 24 weeks achieved by lixisenatide as compared with placebo in the GetGoal-Duo I study. (C) Mean reduction in body weight from baseline at 24 weeks achieved by lixisenatide as compared with placebo in the GetGoal-Duo I study. ${ }^{50}$

Abbreviations: $\mathrm{HbA}_{1 \mathrm{c}}$, glycosylated hemoglobin; PPG, postprandial glucose. 

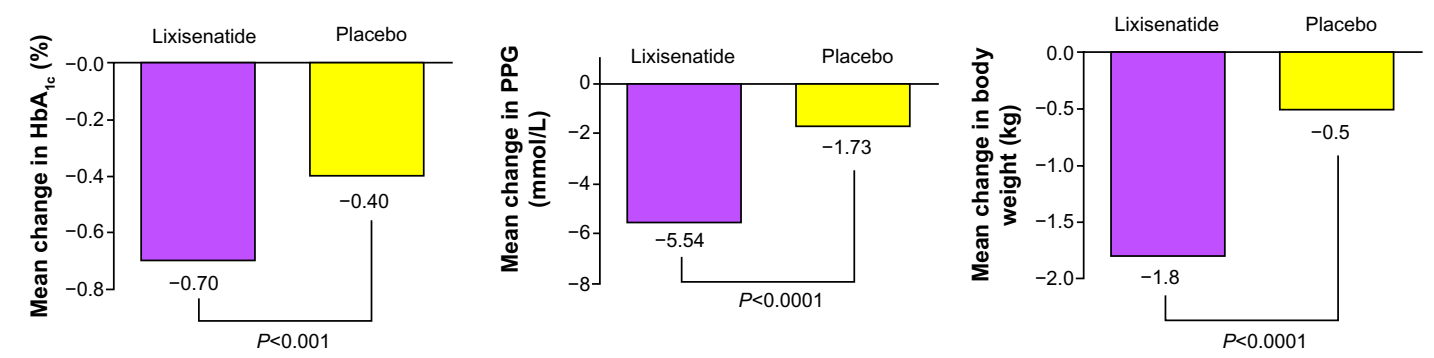

Figure 2 (A) Mean reduction in $\mathrm{HbA}_{\mathrm{Ic}}$ from baseline at 24 weeks achieved by lixisenatide as compared with placebo in the GetGoal-L study ${ }^{51}(P<0.000 \mathrm{I})$. (B) Mean reduction in PPG from baseline at 24 weeks achieved by lixisenatide as compared with placebo in the GetGoal-L study. (C) Mean reduction in body weight from baseline at 24 weeks achieved by lixisenatide as compared with placebo in the GetGoal-L study. ${ }^{51}$

Abbreviations: $\mathrm{HbA}_{\mathrm{lc}}$, glycosylated hemoglobin; PPG, postprandial glucose.

discontinued in $7.6 \%$ of patients in the lixisenatide cohort compared with $4.8 \%$ in the placebo cohort, with the majority of these discontinuations resulting from adverse gastrointestinal events. Nausea was experienced by $86(26.2 \%)$ and $14(8.4 \%)$ patients in the lixisenatide and placebo cohorts, respectively, and vomiting by $27(8.2 \%)$ and one $(0.6 \%)$. Symptomatic hypoglycemia was reported in 91 (27.7\%) and $36(21.6 \%)$ of those receiving lixisenatide and placebo, respectively, with no significant difference between these proportions. There were four $(1.2 \%)$ cases of severe hypoglycemia in the lixisenatide cohort, with no cases in the placebo cohort.

\section{GetGoal-L-Asia: add-on therapy to basal insulin \pm sulfonylurea}

The incidence of adverse events was higher in the lixisenatide cohort, with most being mild to moderate gastrointestinal events that did not require treatment or related to hypoglycemia. Treatment discontinuation occurred in 14 (9.1\%) patients receiving lixisenatide compared with five (3.2\%) on placebo, mainly as a result of adverse gastrointestinal events, especially nausea and vomiting, occurring in six

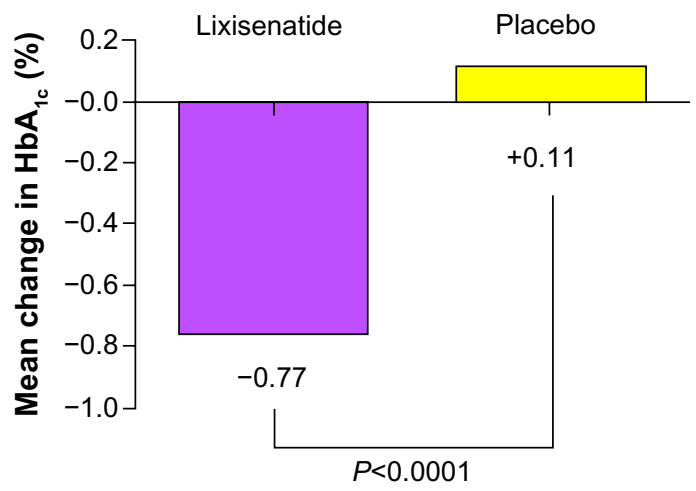

$(3.9 \%)$ and four $(2.6 \%)$, respectively. There were no treatment discontinuations in the placebo cohort resulting from these adverse events. Treatment had to be discontinued in two patients $(1.3 \%)$ in the lixisenatide cohort due to cerebrovascular infarction in the form of nonfatal ischemic stroke. There were similar numbers of serious adverse events between the two cohorts, ie, ten (6.5\%) and nine (5.7\%) for lixisenatide and placebo, respectively. One fatality was reported, being a suicide in the placebo cohort. Hypoglycemia was the most common adverse event in the lixisenatide cohort, with 66 $(42.9 \%)$ patients experiencing symptomatic hypoglycemia compared with 37 (23.6\%) in the placebo cohort, but no case in either cohort was severe. Analyses of the groups of patients not receiving a sulfonylurea demonstrated a similar incidence of hypoglycemia between the lixisenatide and placebo cohorts (32.6\% versus $28.3 \%$, respectively). There were no reported cases of pancreatitis, but there were two cases of raised lipase levels, one in the lixisenatide cohort and one in the placebo cohort. There were no adverse thyroid events or changes in calcitonin levels. Two patients in each cohort reported nonserious injection site reactions, but these did not warrant discontinuation of treatment. There was one

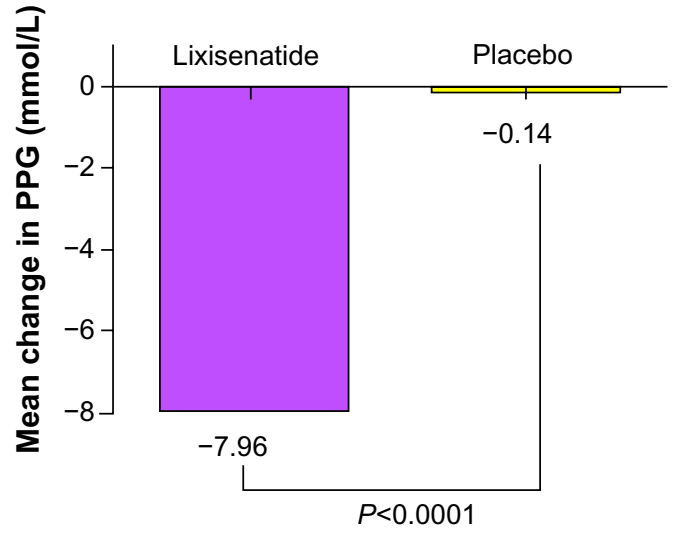

Figure 3 (A) Mean reduction in $\mathrm{HbA}_{\mathrm{Ic}}$ from baseline at 24 weeks achieved by lixisenatide as compared with placebo in the GetGoal-L-Asia study ${ }^{52}(P<0.000 \mathrm{I})$. (B) Mean reduction in PPG from baseline at 24 weeks achieved by lixisenatide as compared with placebo in the GetGoal-L-Asia study. ${ }^{52}$

Abbreviations: $\mathrm{HbA}_{1 \mathrm{c}}$, glycosylated hemoglobin; PPG, postprandial glucose. 
Table 4 Adverse events experienced by patients during the GetGoal-X study ${ }^{49}$ designed to assess the efficacy, safety, and tolerability of lixisenatide as compared with exenatide (unpublished data provided by Sanofi December 20I2)

\begin{tabular}{lll}
\hline Adverse events (n) & $\begin{array}{l}\text { Lixisenatide } \\
\mathbf{2 0} \boldsymbol{\mu g} \text { once daily } \\
\mathbf{n = 3 ~ I 8}\end{array}$ & $\begin{array}{l}\text { Exenatide } \\
\mathbf{I 0} \boldsymbol{\mu} \mathbf{g} \text { twice daily } \\
\mathbf{n = 3 ~ I 6 ~}\end{array}$ \\
\hline Total & $69.5 \%(22 \mathrm{I})$ & $\mathbf{7 2 . 2 \% ( 2 2 8 )}$ \\
Serious & $2.8 \%(9)$ & $2.2 \%(7)$ \\
Leading to death & $0.3 \%(\mathrm{I})$ & $0.3 \%(\mathrm{I})$ \\
Leading to discontinuation & $10.4 \%(33)$ & $13 \%(4 \mathrm{I})$ \\
Gastrointestinal (All) & $43.1 \%(\mathrm{I} 37)$ & $50.6 \%(160)$ \\
Nausea & $24.5 \%(78)$ & $35.1 \%(11 \mathrm{I})$ \\
Vomiting & $10.1 \%(32)$ & $13.3 \%(42)$ \\
Diarrhea & $10.4 \%(33)$ & $13.3 \%(42)$ \\
Patients with hypoglycemia & $2.5 \%(8)$ & $7.9 \%(25)$ \\
Hypoglycemic events & $2.5 \%(8)$ & $15.2 \%(48)$ \\
Severe hypoglycemia & $0 \%$ & $0 \%$ \\
\hline
\end{tabular}

allergic reaction assessed to be related to the study medication in the form of urticaria and six other possible allergic reactions (five in the lixisenatide cohort versus two in the placebo cohort).

\section{Analysis of safety and tolerability}

Overall, lixisenatide was well tolerated as add-on therapy to basal insulin in all three studies, making this agent a novel therapeutic option. Although the incidence of adverse events was higher in the lixisenatide cohort, this is to be expected with additional combination therapies. Importantly, the numbers of serious adverse events were similar between the lixisenatide and placebo cohorts. Adverse gastrointestinal events, such as mild and transient nausea and vomiting in particular, were the most common, as with the other incretin therapies. GetGoal-L and GetGoal-Duo1 demonstrated a largely similar profile of adverse events; however, GetGoalL-Asia differed slightly with a higher incidence of transient nausea and vomiting. This is counterbalanced by the fact that hypoglycemic events were not increased with lixisenatide in the absence of a concomitant sulfonylurea. These observations are in keeping with the evidence that incretin therapies are more effective in Asian populations due to the fact that their T2DM is characterized by a more profound insulin deficit rather than decreased insulin sensitivity. ${ }^{53-55}$

\section{GetGoal: pooled analysis of efficacy and safety of lixisenatide in the elderly and very elderly}

A significant proportion of patients with T2DM are elderly ( $>65$ years) or very elderly ( $>75$ years). It is therefore of the utmost importance that lixisenatide has an appropriate safety, tolerability, and efficacy profile in this age group. A pooled analysis of six studies from the GetGoal program assessed the efficacy of lixisenatide in this patient group through mean differences in $\mathrm{HbA}_{1 \mathrm{c}}$ from baseline. ${ }^{57}$ Safety and tolerability were also assessed by treatment-related adverse events. The results demonstrated that lixisenatide had comparable efficacy regardless of age, with mean reductions in $\mathrm{HbA}_{1 \mathrm{c}}$ from baseline of $0.95 \%$ and $-1.02 \%$ for patients $\geq 65$ years and $\geq 75$ years, respectively. The safety profile of lixisenatide across all age groups was largely similar in terms of hypoglycemia and adverse gastrointestinal events. Overall, the results of this pooled analysis demonstrate that lixisenatide was well tolerated in all age groups, with similar efficacy and perhaps most importantly, no increase in the incidence of symptomatic hypoglycemia in the elderly and very elderly.

\section{Medullary thyroid cancer}

There is currently uncertainty regarding the small correlation between GLP-1 receptor agonists and medullary thyroid carcinoma. Chronic GLP-1 administration in rodents has been linked to increased serum calcitonin levels and C-cell tumor formation. ${ }^{58-61}$ This link has yet to be established in humans and may be a genotype-specific reaction in rodents. There is also no current evidence from the GetGoal studies

Table 5 Summary of adverse events experienced by patients in GetGoal-L,, ${ }^{51}$ GetGoal-L-Asia, ${ }^{52}$ and GetGoal-Duol (unpublished data provided by Sanofi December 20I2)

\begin{tabular}{|c|c|c|c|c|c|c|}
\hline \multirow[t]{2}{*}{ Adverse events (n) } & \multicolumn{2}{|l|}{ GetGoal-L } & \multicolumn{2}{|c|}{ GetGoal-L-Asia } & \multicolumn{2}{|c|}{ GetGoal-Duo I } \\
\hline & $\begin{array}{l}\text { Lixisenatide } \\
n=328\end{array}$ & $\begin{array}{l}\text { Placebo } \\
n=167\end{array}$ & $\begin{array}{l}\text { Lixisenatide } \\
n=\mid 54\end{array}$ & $\begin{array}{l}\text { Placebo } \\
n=157\end{array}$ & $\begin{array}{l}\text { Lixisenatide } \\
n=223\end{array}$ & $\begin{array}{l}\text { Placebo } \\
n=223\end{array}$ \\
\hline Total & $73.5 \%(24 I)$ & $68.3 \%(114)$ & $89 \%(137)$ & $70.1 \%(110)$ & $79.8 \%(178)$ & $68.2 \%(152)$ \\
\hline Serious & $3.7 \%(12)$ & $4.2 \%(7)$ & $6.5 \%(10)$ & $5.7 \%(9)$ & $7.6 \%(17)$ & $4.5 \%(10)$ \\
\hline Leading to death & $0.3 \%$ & 0 & 0 & $0.6 \%(I)$ & 0 & $0.9 \%(2)$ \\
\hline Leading to discontinuation & $7.6 \%$ & $4.8 \%(8)$ & $9.1 \%(14)$ & $3.2 \%(5)$ & $8.5 \%(19)$ & $3.6 \%(8)$ \\
\hline Gastrointestinal & $40.2 \%$ & $20.4 \%(34)$ & $61 \%(94)$ & $14.6 \%(23)$ & $39.9 \%(89)$ & $16.1 \%(36)$ \\
\hline Diarrhea & $7.3 \%$ & $5.4 \%(9)$ & $6.5 \%(10)$ & $2.5 \%(4)$ & $6.7 \%(15)$ & $3.1 \%(7)$ \\
\hline Nausea & $26.2 \%$ & $8.4 \%(14)$ & $39.6 \%(61)$ & $4.5 \%(7)$ & $27.4 \%(6 I)$ & $4.9 \%(11)$ \\
\hline Vomiting & $8.2 \%$ & $0.6 \%(1)$ & $18.2 \%(28)$ & $1.9 \%(3)$ & $9.4 \%(21)$ & $\mathrm{I} .3 \%(3)$ \\
\hline
\end{tabular}


indicating a link between lixisenatide and medullary thyroid carcinoma. GetGoal-L-Asia included parameters monitoring calcitonin levels and revealed no abnormalities. However, all currently available GLP-1 receptor agonists carry a black box warning regarding the risk of C-cell and medullary thyroid carcinoma, so should not be prescribed in individuals with a personal or family history of medullary thyroid carcinoma nor in individuals with multiple endocrine neoplasia syndrome type $2 .{ }^{19,20,22}$ As of yet, no link has been established in clinical studies between lixisenatide and the incidence of $\mathrm{C}$-cell or medullary thyroid carcinoma. Further clinical studies using calcitonin levels as a parameter will provide more information on any risks associated with lixisenatide. As with all novel drug approvals, closely monitored post-marketing surveillance is essential and paramount to safe use in clinical practice.

\section{Future directions: lixisenatide Reducing glycemic variability}

The incretin therapies in general carry a low risk of hypoglycemia due to their mechanism of action which stimulates only glucose-dependent insulin release and limits alpha cell postprandial glucagon secretion. ${ }^{62,63}$ Lixisenatide has this attribute and also appears to reduce PPG without decreasing fasting plasma glucose to a greater extent than current GLP-1 receptor agonists. We hypothesize that this may reduce glycemic variability by helping to limit significant upwards or downwards glucose excursions.

Glycemic variability refers to acute upwards and downwards glucose changes and is a component of dysglycemia. ${ }^{64}$ Fasting plasma glucose is only a value measured at a specific point in time and does not give an indication of acute glucose swings. Similarly, although $\mathrm{HbA}_{1 \mathrm{c}}$ is a good marker of longer-term glycemia, patients with similar $\mathrm{HbA}_{1 \mathrm{c}}$ levels can have very different glycemic excursions. Glycemic variability may have a key role in the development of atherosclerosis, as well as being a risk factor for cardiovascular complications in patients with T2DM, ${ }^{46,65,66}$ this is due to the fact that acute glucose excursions increase oxidative stress. ${ }^{64}$ Currently, there are no results from studies relating to the association between lixisenatide and major cardiovascular endpoints; however, ELIXA (Evaluation of cardiovascular outcomes in patients with T2DM after acute coronary syndrome during treatment with lixisenatide) may provide valuable data. ${ }^{67}$

\section{ELIXA study}

ELIXA is an event-driven, multicenter study assessing the effect of lixisenatide on cardiovascular outcomes. ${ }^{67}$ Patients with T2DM were recruited following an acute coronary syndrome. The primary outcome of the study was time to the first cardiovascular event, including cardiovascular death, nonfatal myocardial infarction, nonfatal stroke, or hospitalization for unstable angina. The study will stop when 844 events have occurred, and the expected completion date is presently September 2014. A recent study by Su et al found that following an acute myocardial infarction, glycemic variability was a better predictor of major adverse cardiovascular events at one year than $\mathrm{HbA}_{1 \mathrm{c}}{ }^{64}$ Positive results in the ELIXA study may therefore contribute to a body of evidence suggesting that an all-encompassing glucose lowering strategy may be just as effective, if not more effective, than targeting fasting plasma glucose alone. It is worth mentioning that, on September 12, 2013, Sanofi decided to delay the approval process for lixisenatide in the US until full data from the ELIXA study are available. Sanofi is expected to resubmit the application in $2015 .^{68}$

\section{Conclusion: place in practice}

The primary license indication of lixisenatide is in combination with oral antidiabetic agents or basal insulin, with the latter being particularly relevant given the large number of patients in the UK currently using basal insulin. The evidence suggests that $35 \%-63.5 \%$ of patients do not achieve target $\mathrm{HbA}_{1 \mathrm{c}}$ levels despite using basal insulin, ${ }^{69}$ with median $\mathrm{HbA}_{1 \mathrm{c}}$ levels of $62(7.8 \%)$ to $69 \mathrm{mmol} / \mathrm{mol}$ $(8.5 \%)$ at 24 months. ${ }^{70}$ Although a variety of factors may account for this, including suboptimal insulin dose titration or high baseline levels of $\mathrm{HbA}_{1 \mathrm{c}}$ at insulin initiation, the impact of PPG appears to be a key factor. ${ }^{35}$ This is especially relevant in patients who are already achieving optimum fasting plasma glucose levels and are still unable to achieve $\mathrm{HbA}_{1 \mathrm{c}}$ targets. Lixisenatide is the first once-daily prandial GLP-1 agonist to become available, and is also the most studied in combination with basal insulin. Although there are not enough long-term data to definitively state whether the adverse events profile of lixisenatide is superior to that of other GLP-1 agonists, the current evidence is promising. In addition to this, targeting PPG excursions without dramatically impacting fasting plasma glucose levels may help to limit glycemic variability, leading to better cardiovascular outcomes. This is especially relevant in patients initiated on basal insulin, given that they are particularly prone to glucose swings. In conclusion, the current evidence suggests that lixisenatide may be a useful complementary add-on to basal insulin, offering patients minimal additional side effects whilst optimizing PPG and potentially reducing glycemic variability. 


\section{Disclosure}

Production of this paper was supported by Sanofi, which provided a grant and also checked the content for technical accuracy. ME has previously received consulting fees for advisory board participation with Sanofi. The authors report no other conflicts of interest in this work.

\section{References}

1. Holst JJ, Vilsboll T, Deacon CF. The incretin system and its role in type 2 diabetes mellitus. Mol Cell Endocrinol. 2009;297(1-2): $127-136$.

2. Knop FK, Vilsboll T, Hojberg PV, et al. Reduced incretin effect in type 2 diabetes: cause or consequence of the diabetic state? Diabetes. 2007;56(8):1951-1959.

3. McIntyre N, Holdsworth CD, Turner DS. New interpretation of oral glucose tolerance. Lancet. 1964;2(7349):20-21.

4. Perry T, Greig NH. The glucagon-like peptides: a double-edged therapeutic sword? Trends Pharmacol Sci. 2003;24(7): 377-383.

5. Drucker DJ, Nauck MA. The incretin system: glucagon-like peptide-1 receptor agonists and dipeptidyl peptidase- 4 inhibitors in type 2 diabetes. Lancet. 2006;368(9548):1696-1705.

6. Neumiller JJ, Setter SM. Review of linagliptin for the treatment of type 2 diabetes mellitus. Clin Ther. 2012;34(5):993-1005.

7. Barnett A. DPP-4 inhibitors and their potential role in the management of type 2 diabetes. Int J Clin Pract. 2006;60(11):1454-1470.

8. Nathan DM, Buse JB, Davidson MB, et al. Medical management of hyperglycemia in type 2 diabetes: a consensus algorithm for the initiation and adjustment of therapy: a consensus statement of the American Diabetes Association and the European Association for the Study of Diabetes. Diabetes Care. 2009;32(1):193-203.

9. Morales J. The pharmacologic basis for clinical differences among GLP-1 receptor agonists and DPP-4 inhibitors. Postgrad Med. 2011;123(6):189-201.

10. Elkinson S, Keating GM. Lixisenatide: first global approval. Drugs. 2013;73(4):383-391.

11. Kim D, Wang L, Beconi M, et al. (2R)-4-oxo-4-[3-(trifluoromethyl)5,6-dihydro[1,2,4]triazolo[4,3-a]pyrazin-7(8H)-yl]-1-(2,4,5-trifluorophenyl)butan-2-amine: a potent, orally active dipeptidyl peptidase IV inhibitor for the treatment of type 2 diabetes. J Med Chem. 2005;48(1):141-151.

12. Augeri DJ, Robl JA, Betebenner DA, et al. Discovery and preclinical profile of saxagliptin (BMS-477118): a highly potent, long-acting, orally active dipeptidyl peptidase IV inhibitor for the treatment of type 2 diabetes. J Med Chem. 2005;48(15):5025-5037.

13. Villhauer EB, Brinkman JA, Naderi GB, et al. 1-[[(3-hydroxy-1adamantyl)amino]acetyl]-2-cyano-(S)-pyrrolidine: a potent, selective, and orally bioavailable dipeptidyl peptidase IV inhibitor with antihyperglycemic properties. J Med Chem . 2003;46(13):2774-2789.

14. National Institute for Clinical Excellence. NICE Clinical Guideline 87. The management of type 2 diabetes. 2011. Available from: http:// www.nice.org.uk/nicemedia/live/12165/44320/44320.pdf. Accessed November 6, 2013.

15. DeFronzo RA, Okerson T, Viswanathan P, Guan X, Holcombe JH, MacConell L. Effects of exenatide versus sitagliptin on postprandial glucose, insulin and glucagon secretion, gastric emptying, and caloric intake: a randomized, cross-over study. Curr Med Res Opin. 2008;24(10):2943-2952.

16. Thong KY, Jose B, Sukumar N, et al. Safety, efficacy and tolerability of exenatide in combination with insulin in the Association of British Clinical Diabetologists nationwide exenatide audit*. Diabetes Obes Metab. 2011;13(8):703-710.

17. Buse JB, Bergenstal RM, Glass LC, et al. Use of twice-daily exenatide in basal insulin-treated patients with type 2 diabetes: a randomized, controlled trial. Ann Intern Med. 2011;154(2):103-112.
18. DeVries JH, Bain SC, Rodbard HW, et al. Sequential intensification of metformin treatment in type 2 diabetes with liraglutide followed by randomized addition of basal insulin prompted by $\mathrm{A}_{1 \mathrm{c}}$ targets. Diabetes Care. 2012;35(7):1446-1454.

19. European Medicines Agency. Summary of product characteristics: Exenatide. 2012. Available from: http://www.ema.europa.eu/docs/en_ GB/document_library/EPAR_-_Product_Information/human/000698/ WC500051845.pdf. Accessed February 7, 2012.

20. European Medicines Agency. Summary of product characteristics: Bydureon. 2012. Available from: http://www.ema.europa.eu/docs/en_ GB/document_library/EPAR_-_Product_Information/human/002020/ WC500108241.pdf. Accessed February 7, 2012.

21. Food and Drug Administration. Drug details: Victoza. 2013. Available from: http://www.accessdata.fda.gov/scripts/cder/drugsatfda/index. cfm?fuseaction=Search.DrugDetails. Accessed February 8, 2013.

22. European Medicines Agency. Summary of product characteristics: Liraglutide. 2012. Available from: http://www.ema.europa.eu/docs/en_ GB/document_library/EPAR_-_Product_Information/human/001026/ WC500050017.pdf. Accessed February 7, 2012.

23. Monnier L, Colette $\mathrm{C}$, Boniface $\mathrm{H}$. Contribution of postprandial glucose to chronic hyperglycaemia: from the "glucose triad" to the trilogy of “sevens". Diabetes Metab. 2006;32 Spec No 2:2S11-S16.

24. Monnier L, Colette C. Contributions of fasting and postprandial glucose to hemoglobin $\mathrm{A}_{1 \mathrm{c}}$. Endocr Pract. 2006;12 Suppl 1:42-46.

25. Barnett AH. Lixisenatide: evidence for its potential use in the treatment of type 2 diabetes. Core Evid. 2011;6:67-79.

26. European Medicines Agency. Summary of product characteristics: Lyxumia. 2012. Available from: http://www.ema.europa.eu/ema/index. jsp?curl=pages/medicines/human/medicines $/ 002445 /$ smops $/$ Positive/ human_smop_000448.jsp\&mid=WC0b01ac058001d127. Accessed February 1, 2013.

27. National Institute for Clinical Excellence. NICE CG87. 2013. Available from: http://www.nice.org.uk/nicemedia/pdf/CG87QuickRefGuide.pdf. Accessed May 6, 2013.

28. Christensen M, Knop FK, Holst JJ, Vilsboll T. Lixisenatide, a novel GLP-1 receptor agonist for the treatment of type 2 diabetes mellitus. IDrugs. 2009;12(8):503-513.

29. Christensen M, Knop FK, Vilsboll T, Holst JJ. Lixisenatide for type 2 diabetes mellitus. Expert Opin Investig Drugs. 2011;20(4): 549-557.

30. Buse JB, Rosenstock J, Sesti G, et al. Liraglutide once a day versus exenatide twice a day for type 2 diabetes: a 26-week randomised, parallel-group, multinational, open-label trial (LEAD-6). Lancet. 2009;374(9683):39-47.

31. Lorenz M, Pfeiffer C, Steinstrasser A, Ruus P, Becker RH. Effects of lixisenatide once daily on gastric emptying and its relationship to postprandial glycaemia in type 2 diabetes mellitus. Poster 1085-P presented at the 72 nd Scientific Sessions of the American Diabetes Association, June 8-12, 2012, Philadelphia, PA, USA.

32. Bolli G, Munteanu M, Dotsenko S, Niemoeller E, Boka G, Hanefeld M. Efficacy and safety of lixisenatide once-daily versus placebo in patients with T2DM insufficiently controlled on metformin (GetGoalF1). Diabetes Care. 2011;54 Suppl 1:A784.

33. Monnier L, Colette C, Dunseath GJ, Owens DR. The loss of postprandial glycemic control precedes stepwise deterioration of fasting with worsening diabetes. Diabetes Care. 2007;30(2):263-269.

34. Kapitza C, Forst T, Coester HV, Poitiers F, Ruus P, Hincelin-Mery A. Pharmacodynamic characteristics of lixisenatide once daily versus liraglutide once daily in patients with type 2 diabetes insufficiently controlled on metformin. Diabetes Obes Metab. 2013;15(7):642-649.

35. Riddle M, Umpierrez G, DiGenio A, Zhou R, Rosenstock J. Contributions of basal and postprandial hyperglycemia over a wide range of $\mathrm{A}_{1 \mathrm{c}}$ levels before and after treatment intensification in type 2 diabetes. Diabetes Care. 2011;34(12):2508-2514.

36. Monnier L, Lapinski H, Colette C. Contributions of fasting and postprandial plasma glucose increments to the overall diurnal hyperglycemia of type 2 diabetic patients: variations with increasing levels of HbA(1c). Diabetes Care. 2003;26(3):881-885. 
37. Monnier L, Colette C, Owens D. Postprandial and basal glucose in type 2 diabetes: assessment and respective impacts. Diabetes Technol Ther. 2011;13 Suppl 1:S25-S32.

38. Schernthaner G, Guerci B, Gallwitz B, et al. Impact of postprandial and fasting glucose concentrations on $\mathrm{HbA}_{1 \mathrm{c}}$ in patients with type 2 diabetes. Diabetes Metab. 2010;36(5):389-394.

39. Landgraf R. The relationship of postprandial glucose to $\mathrm{HbA}_{1 \mathrm{c}}$. Diabetes Metab Res Rev. 2004;20 Suppl 2:S9-S12.

40. Sloop KW, Willard FS, Brenner MB, et al. Novel small molecule glucagon-like peptide-1 receptor agonist stimulates insulin secretion in rodents and from human islets. Diabetes. 2010;59(12):3099-3107.

41. Kim YW, Kim KH, Choi HJ, Lee DS. Anti-diabetic activity of betaglucans and their enzymatically hydrolyzed oligosaccharides from Agaricus blazei. Biotechnol Lett. 2005;27(7):483-487.

42. Panahi S, Ezatagha A, Temelli F, Vasanthan T, Vuksan V. Beta-glucan from two sources of oat concentrates affect postprandial glycemia in relation to the level of viscosity. J Am Coll Nutr. 2007;26(6):639-644.

43. Meier JJ. GLP-1 receptor agonists for individualized treatment of type 2 diabetes mellitus. Nat Rev Endocrinol. 2012;8(12):728-742.

44. Cervera A, Wajcberg E, Sriwijitkamol A, et al. Mechanism of action of exenatide to reduce postprandial hyperglycemia in type 2 diabetes. Am J Physiol Endocrinol Metab. 2008;294(5):E846-E852.

45. Linnebjerg H, Park S, Kothare PA, et al. Effect of exenatide on gastric emptying and relationship to postprandial glycemia in type 2 diabetes Regul Pept. 2008;151(1-3):123-129.

46. Su G, Mi S, Tao H, et al. Association of glycemic variability and the presence and severity of coronary artery disease in patients with type 2 diabetes. Cardiovasc Diabetol. 2011;10:19.

47. Ratner RE, Hanefeld M, Shamanna P, et al. Efficacy and safety of lixisenatide once-daily versus placebo in patients with type 2 diabetes mellitus insufficiently controlled on sulfonylurea \pm metformin (GetGoalS). Diabetologia. 2011;54 Suppl 1:A785.

48. Pinget M, Goldenberg R, Niemoeller E, Muehlen-Bartmer I, Aronson R. Efficacy and safety of lixisenatide once daily versus placebo in patients with type 2 diabetes insufficiently controlled on pioglitazone. (GetGoal-P). Poster 1010-P presented at the 72nd Scientific Sessions of the American Diabetes Association, June 8-12, 2012, Philadelphia, PA, USA.

49. Rosenstock J, Raccah D, Koranyi L, etal. Efficacy and safety of lixisenatide once daily versus exenatide twice daily in type 2 diabetes inadequately controlled on metformin: a 24-week, randomized, open-label, active-controlled study (GetGoal-X). Diabetes Care. 2013;36(10):2945-2951.

50. Riddle MC, Forst T, Aronson R, etal. Adding once-daily lixisenatide for type 2 diabetes inadequately controlled with newly initiated and continuously titrated basal insulin glargine: a 24-week, randomized, placebo-controlled study (GetGoal-Duo 1). Diabetes Care. 2013;36(9): 2497-2503.

51. Riddle MC, Aronson R, Home P, etal. Adding once-daily lixisenatide for type 2 diabetes inadequately controlled by established basal insulin: a 24-week, randomized, placebo-controlled comparison (GetGoal-L). Diabetes Care. 2013;36(9):2489-2496.

52. Seino Y, Min KW, Niemoeller E, Takami A; EFC10887 GETGOAL-L Asia Study Investigators. Randomized, double-blind, placebo-controlled trial of the once-daily GLP-1 receptor agonist lixisenatide in Asian patients with type 2 diabetes insufficiently controlled on basal insulin with or without a sulfonylurea (GetGoal-L-Asia). Diabetes Obes Metab. 2012;14(10):910-917.

53. Yabe D, Seino Y. Two incretin hormones GLP-1 and GIP: comparison of their actions in insulin secretion and beta cell preservation. Prog Biophys Mol Biol. 2011;107(2):248-256.

54. Yabe D, Kuroe A, Lee S, etal. Little enhancement of meal-induced glucagon-like peptide1 secretion in Japanese: comparison of type 2 diabetes patients and healthy controls. J Diabetes Investig. 2010;1(1-2): 56-59.

55. Yabe D, Watanabe K, Sugawara K, etal. Comparison of incretin immunoassays with or without plasma extraction: incretin secretion in Japanese patients with type 2 diabetes. J Diabetes Investig. 2012;3(1):70-79.
56. Fineman MS, Cirincione BB, Maggs D, Diamant M. GLP-1 based therapies: differential effects on fasting and postprandial glucose. Diabetes Obes Metab. 2012;14(8):675-688.

57. Raccah D, Miossec P, Esposito V, Niemoeller E, Cho M, Gerich JE. Efficacy and safety of lixisenatide in elderly (\$65 yr) and very elderly (\$75 yr) patients with type 2 diabetes: an analysis from the GetGoal Phase 3 program. Poster P972 presented at the 72nd Scientific Sessions of the American Diabetes Association, June 8-12, 2012, Philadelphia, PA, USA.

58. Hegedus L, Moses AC, Zdravkovic M, Le Thi T, Daniels GH. GLP-1 and calcitonin concentration in humans: lack of evidence of calcitonin release from sequential screening in over 5000 subjects with type 2 diabetes or nondiabetic obese subjects treated with the human GLP-1 analog, liraglutide. J Clin Endocrinol Metab. 2011;96(3):853-860.

59. Crespel A, De Boisvilliers F, Gros L, Kervran A. Effects of glucagon and glucagon-like peptide-1-(7-36) amide on $\mathrm{C}$ cells from rat thyroid and medullary thyroid carcinoma CA-77 cell line. Endocrinology. 1996;137(9):3674-3680.

60. Bulchandani D, Nachnani JS, Herndon B, etal. Effect of exendin (exenatide) - GLP 1 receptor agonist on the thyroid and parathyroid gland in a rat model. Eur J Pharmacol. 2012;691(1-3):292-296.

61. Madsen LW, Knauf JA, Gotfredsen C, etal. GLP-1 receptor agonists and the thyroid: C-cell effects in mice are mediated via the GLP-1 receptor and not associated with RET activation. Endocrinology. 2012;153(3): $1538-1547$.

62. Naslund E, Bogefors J, Skogar S, etal. GLP-1 slows solid gastric emptying and inhibits insulin, glucagon, and PYY release in humans. Am J Physiol. 1999;277(3 Pt 2):R910-R916.

63. Campbell RK, Cobble ME, Reid TS, Shomali ME. Distinguishing among incretin-based therapies. Safety, tolerability, and nonglycemic effects of incretin-based therapies. J Fam Pract. 2010; 59(9 Suppl 1): S20-S27.

64. Su G, Mi SH, Tao H, etal. Impact of admission glycemic variability, glucose, and glycosylated hemoglobin on major adverse cardiac events after acute myocardial infarction. Diabetes Care. 2013;36(4): 1026-1032.

65. Hu Y, Liu W, Huang R, Zhang X. Postchallenge plasma glucose excursions, carotid intima-media thickness, and risk factors for atherosclerosis in Chinese population with type 2 diabetes. Atherosclerosis. 2010;210(1):302-306.

66. Lachin JM, Genuth S, Nathan DM, Zinman B, Rutledge BN. Effect of glycemic exposure on the risk of microvascular complications in the diabetes control and complications trial - revisited. Diabetes. 2008; 57(4):995-1001.

67. Clinical Trials.gov. Evaluation of cardiovascular outcomes in patients with type 2 diabetes after acute coronary syndrome during treatment with AVE0010 (lixisenatide) (ELIXA). Available from: http://clinicaltrials. gov/show/NCT01147250. Accessed April 15, 2013.

68. Sanofi. Sanofi provides update on lixisenatide new drug application in US. Available from: http://www.sanofi.dk/1/dk/da/download. jsp?file=5DDB9554-F37A-40D9-A1F3-C91F7BE06C9B.pdf. Accessed October 27, 2013.

69. Giugliano D, Maiorino MI, Bellastella G, Chiodini P, Ceriello A, Esposito K. Efficacy of insulin analogs in achieving the hemoglobin A1c target of ,7\% in type 2 diabetes: meta-analysis of randomized controlled trials. Diabetes Care. 2011;34(2):510-517.

70. Watson L, Wilson BP, Alsop J, Kumar S. Weight and glycaemic control in type 2 diabetes: what is the outcome of insulin initiation? Diabetes Obes Metab. 2011;13(9):823-831.

71. Ahren B, Leguizamo Dimas A, Miossec P, Saubadu S, Aronson R. Efficacy and safety of lixisenatide once-daily morning or evening injections in type 2 diabetes inadequately controlled on metformin (GetGoal-M). Diabetes Care. 2013;36(9):2543-2550.

72. Fonseca VA, Alvarado-Ruiz R, Raccah D, Boka G, Miossec P, Gerich JE. Efficacy and safety of the once-daily GLP-1 receptor agonist lixisenatide in monotherapy: a randomized, double-blind, placebo-controlled trial in patients with type 2 diabetes (GetGoal-Mono). Diabetes Care. 2012;35(6):1225-1231. 


\section{Publish your work in this journal}

Drug Design, Development and Therapy is an international, peerreviewed open-access journal that spans the spectrum of drug design and development through to clinical applications. Clinical outcomes, patient safety, and programs for the development and effective, safe, and sustained use of medicines are a feature of the journal, which

has also been accepted for indexing on PubMed Central. The manuscript management system is completely online and includes a very quick and fair peer-review system, which is all easy to use. Visit http://www.dovepress.com/testimonials.php to read real quotes from published authors.

Submit your manuscript here: http://www.dovepress.com/drug-design-development-and-therapy-journal 